\title{
A Comparative Study of Stress and Alienation among Orphans and Normal
}

\author{
Dr. Seema Irshad ${ }^{1 *}$
}

\section{ABSTRACT}

The present study was undertaken to investigate, (1) Is there any relationship between stress and alienation? (2) Is there any difference between orphans and normal with respect to stress? (3) Is there any difference among orphans and normal with respect to alienation? In addition to these main objectives of the present research are, (1) To find out any relationship between stress and alienation, (2) To find out whether or not orphans and normal significantly differ with respect to stress, (3) To find out whether or not orphans and normal significantly differ with respect to alienation. In this study 40 subjects in each group were analysed which means that there are total 80 subjects in this study. Perceived Stress Scale (PSS, Cohen et. al., 1983) and Alienation Scale by R. V. Patil were used for the collection of data. In order to find out these objectives Pearson correlation and t-test was applied. The results indicated that stress and alienation are highly correlated with each other which means that when a person is under stressful condition they automatically get into alienated and vice versa. Results from t-test clearly show that orphans are higher in alienation and stress in comparison to normal.

Keywords: Stress, Alienation, Orphans, Normal

In the common use, an orphan does not have any surviving parent to care for him or her. However, the United Nations Children's Fund (UNICEF), Joint United Nations Programme on HIV and AIDS (UNAIDS), and other groups label any child that has lost one parent as an orphan. In this approach, a maternal orphan is a child whose mother has died, a paternal orphan is a child whose father has died, and a double orphan has lost both parents. This contrasts with the older use of half-orphan to describe children that had lost only one parent. However, adults can also be referred to as orphans, or "adult orphans". One legal definition used very commonly in the United States is "death or disappearance of, abandonment or desertion by, or separation or loss from, both parents."

\footnotetext{
${ }^{1}$ Assistant Professor at King Faisal University, Saudi Arabia

*Responding Author

Received: January 8, 2017; Revision Received: March 9, 2017; Accepted: March 10, 2017

(C) 2017 Irshad S; licensee IJIP. This is an Open Access Research distributed under the terms of the Creative Commons Attribution License (www.creativecommons.org/licenses/by/2.0), which permits unrestricted use, distribution, and reproduction in any Medium, provided the original work is properly cited.
} 


\section{A Comparative Study of Stress and Alienation among Orphans and Normal}

Orphans and vulnerable children remain a pressing challenge for many countries. By the end of 2003, it was estimated that there were 143 million orphans aged 0-17 years old in 93 countries of sub-Saharan Africa, Asia, Latin America and the Caribbean of the 143 million orphans in the 3 regions, just under 90\% are aged 6-17 years; they are school-aged children.

Death of parents introduces a major change in the life of a vulnerable child. There are very few events in a child's life as traumatic as losing one or both parents (Thompson, Kalsow, Price, Williams \& Kingree 1998). This traumatic event also causes great changes in family situations and the upbringing of children. Children taken care of by grandparents or other relatives mainly facing economic problems with schooling, food and medical care (Nyambedha, Wandibba \& Aagaard-Hansen, 2003a; Ntozi, 1997; Nyambedha, Wandibba \& Aagaard-Hansen 2003b; Sengendo \& Nambi 1997). Those children who choose not to move or who may not have any other relative to go, may be forced to live on their own, constituting child-headed families. All these changes can easily affect not only the physical, but also the psychological well-being of a vulnerable child. Minde (1988) makes it clear that it is not the social change itself that may cause psychological problems; rather it is the failure of the individual to adapt to social change and the resultant need to adapt to it create stress. Orphaned children are also more likely to get cognitive difficulties and might lack the access to education completely (UNICEF 2003). They have also reported difficulty in concentrating at school due to worries, sadness or tiredness (Forehand et. al., 1999, Giese et. al., 2001). Literature also suggests somatic symptoms (Thomas et. al., 2002), which may be a useful indicator of distress amongst children in South Africa (Swartz, et. al., 2002). Finally, friendship difficulties related to stigma have been found in both qualitative (ACESS, 2002; Giese et. al., 2001) and quantitative studies (Manuel, 2002; Makame, et. al., 2002).

One of the considerations that motivated the researcher to undertake the present study is to find out whether orphans and normal people differ with respect to stress or they vary to respond to a stressful situation.

Modern life is full of hassles, deadlines, frustrations, and demands. For many people, stress is so commonplace that it has become a way of life. The term stress was first employed in a biological context by the endocrinologist Hans Selye in the 1930s. The word 'stress' refers to the response you have when facing circumstances that force you to act, change, or adjust in some way to maintain your footing, or to keep things balanced. Oxford Dictionary defined stress as "a state of affair involving demand on physical or mental energy". In medical parlance 'stress' is defined as a perturbation of the body's homeostasis which occurs when our body and mind tries to cope with incessant changes in life. In small doses, stress can help people to perform under pressure and motivate them to do their best. 


\section{A Comparative Study of Stress and Alienation among Orphans and Normal}

According to Lazarus, (1966) "It seems wise to use "stress" as a generic term for the whole area of problems that includes the stimuli producing stress reactions, the reactions themselves and the various intervening processes. It defines a large, complex, amorphous, interdisciplinary area of interest and study.”

Aubrey( 2009) described that Chronic stress can significantly affect many of the body's immune systems, as can an individual's perceptions of, and reactions to, stress. He further states that immune system changes can create more vulnerability to infection, and have been observed to increase the potential for an outbreak of psoriasis for people with that skin disorder. Chronic stress has also been shown to impair developmental growth in children by lowering the glands production of growth hormone, as in children associated with a home environment involving serious marital discord, alcoholism, or child abuse (Powell, Brasel, \& Blizzard, 1967).

Another consideration that motivated the author to undertake the present study is to find out whether or not orphans and normal people differ with respect to alienation.

Alienation can be defined as "a state or process in which something is lost by or estranged from the person who originally possessed it" (Harre \& Lamb, 1983). Alienation is nothing but a negative relationship that an adolescent has with the environment. It has been related to antisocial behaviour (Wynne, 1978; Young, 1985) and has been associated with a withdrawal from participation in social institutions, such as the school (Calabrese \& Seldin, 1986; Rafalides \& Hoy, 1971). In psychology and psychiatry alienation is considered as a state of psychological isolation, interpersonal distrust, lack of feelings of competence, uncrystallised sense of identity and the feeling that the individual lacks meaning and authenticity in his life. Many researchers viewed alienation as a combination of powerlessness, isolation, and meaninglessness (Dean, 1961). Throughout the 20th century, the concept of alienation has received substantial attention in the social sciences. During the past 40 years, empirical studies have tried to determine the psychological manifestations of alienation, mostly in adults but also in adolescents (Dean, 1961; Mackey \& Ahlgren, 1977; Mau 1992; Roberts, 1987; Williamson \& Cullingford, 1998).

Calabrese and Adams (1998) investigated the differences in levels of alienation among incarcerated and non-incarcerated adolescents, and found that the incarcerated adolescents did have significantly higher levels of isolation, powerlessness, and over all alienation, but not higher levels of looseness, the more or less similar result was found by Calabrese \& Cochran (1999). An additional attempt has to be made by researcher in Africa to find out what are the correlation between peer victimization and symptoms in children such as social avoidance; rejection; suicide and violence; aggression; posttraumatic stress; depression, conflict; anxiety and social anxiety; general or global self-esteem; and social self-concept (Clearly, 2000; Hanish, 2000 and Gurrera; Hawker and Boulton, 2000; Khatri and Kupersmidt, 2003; Storch, Nock, Masia-Warner, and Barlas, 2003; Storch and Esposito, 2003). 


\section{A Comparative Study of Stress and Alienation among Orphans and Normal}

Furthermore Lieberman \& Morris (2004) conducted a study to identify psychological differences between extra familial adult adoptees and a non-adopted comparison group, results indicated no significant group differences in Ego stage however adoptees were significantly higher on some "Alienation" scores and non-adoptees were significantly higher on some "Affiliation" scores ( $\mathrm{p}<$ .05). Higher levels of maladjustment were found among adopted adult when compared to normal (Cubito and Brandon, 2000; Fletcher, 1997). Overall, the non-adopted group manifested better adjustment than the adopted group (Sharma, McGue, \& Benson, 1996; Maughan, Collishaw, \& Pickles, 1998).

Findings from the literature suggest that orphans are generally disadvantaged compared to nonorphans. Although most orphans are frequently cared of by extended family members, these orphans are more likely to live in households with less favourable dependency ratios and greater experiences of financial hardship (Monasch \& Boerma, 2004; Nyambedha, Wandibba, \& Aagaard-Hansen, 2003a; Nyambedha, Wandibba, \& Aagaard-Hansen, 2003b; Oleke, Blystand, \& Rekdal, 2005; Safman, 2004). Orphans have lower school attendance, lower school completion rates, and/or are less likely than non-orphans to be at the age-appropriate grade level (Bicego, Rutstein, \& Johnson, 2003; Makame et al., 2002; Monasch \& Boerma, 2004; Nyambedha et al., 2003b; Nyamukapa \& Gregson, 2005). Although mixed results about physical health and health care access have been reported among orphans as compared with non-orphans (Crampin et al., 2003; Lindblade, Odhiambo, Rosen, \& DeCock, 2003; Masmas et al., 2004; Nyambedha et al., 2003a; Nyambedha et al., 2003b; Sarker, Neckermann, \& Muller, 2005), psychological problems have been consistently observed among orphans (Atwine, Cantor-Graae, \& Bajunirwe, 2005; Cluver \& Gardner, 2006; Makame et al., 2002; Pelton \& Forehand, 2005).

In the light of above study, it is highly logical to assume that orphans may differ to normal with respect to alienation. It means that orphans are likely to more alienate as compare to normal. The present study is also carried out to test this assumption. The aim of this study was to investigate whether there was any significant difference between the levels of stress and alienation among orphans and normal. Study questions of the present study are:

1. Is there any relationship between stress and alienation?

2. Is there any difference between orphans and normal with respect to stress?

3. Is there any difference among orphans and normal with respect to alienation?

Thus the objectives of the present study are:

1. To find out any relationship between stress and alienation?

2. To find out whether or not orphans and normal significantly differ with respect to stress.

3. To find out whether or not orphans and normal significantly differ with respect to alienation.

The findings of the present study will help in understanding the possible causes that makes orphans differ with normal and how can we help them to live a healthy and normal life. 


\section{A Comparative Study of Stress and Alienation among Orphans and Normal}

\section{METHODOLOGY}

\section{Sample}

Data was collected by using purposive random sampling. Orphans subjects were drawn from Missionaries of Charity (Mother Teresas Home), Aligarh, and normal subjects were from Boys +2 , A.M.U. Aligarh. There were 40 subjects in each group i.e., in all 80 subjects participated in the present study, and the age range was between 14-18 years.

\section{Tools}

Following tools were used in the present investigation:

1. Perceived Stress Scale (PSS, Cohen et. al., 1983): The purpose of this scale is to assess the degree to which people perceive their lives stressful. High levels of stress are associated with poor self-reported health, elevated blood pressure, depression, and susceptibility to infection. The scale consist of ten items with five alternative answer i.e., $1=$ Never to $5=$ Very often. The reliability of the scale was found alpha $=.78$ and also correlated in a predicted way with other measure of stress (Job Responsibilities Scale, life events scales).

2. Alienation Scale: The alienation scale was developed by Patil R.V. It is a selfadministered scale consisted with 20 highly discriminating items followed with three alternative answers 'YES' 'Undecided' and 'NO'. The split half reliability (correlating the odd-even items) of the test is .943, and test retest reliability is .897. The coefficient of correlation of the scale with Reddy, Malla's Alienation Scale and Kureshi and Dutt's are .76 and $.73(\mathrm{~N}=100)$ respectively.

\section{RESULT}

In order to find out the difference between orphans and normal, t-test and correlation coefficient were used to analyze the data. From the table-I we can clearly see that stress and alienation are positively correlated with each other. As findings indicate in table-I that the correlation coefficient $=.603$ significant at .01 level of confidence, indicating that both stress and alienation are positively correlated i.e., when stress increase alienation automatically increases and vice versa, that is more an orphanage-reared child is stressful the more he/she is alienated.

Table-I Showing Pearson Correlation between Stress and Alienation

\begin{tabular}{|c|c|c|c|}
\hline \multirow{2}{*}{ stress } & & stress & Alienation $^{*}$ \\
\cline { 2 - 4 } & Pearson Correlation & 1 & $.603^{* *}$ \\
\cline { 2 - 4 } & Sig. (2-tailed) & & .000 \\
\hline \multirow{2}{*}{ alienation } & $\mathrm{N}$ & $.603^{* *}$ & 80 \\
\cline { 2 - 4 } & Pearson Correlation & .000 & 1 \\
\cline { 2 - 4 } & Sig. (2-tailed) & 80 & 80 \\
\hline
\end{tabular}

(c) The International Journal of Indian Psychology, ISSN 2348-5396 (e)| ISSN: 2349-3429 (p) | 168 
A Comparative Study of Stress and Alienation among Orphans and Normal

\begin{tabular}{|c|c|c|c|}
\hline & & stress & Alienation \\
\hline \multirow{3}{*}{ stress } & Pearson Correlation & 1 & $.603^{* *}$ \\
\cline { 2 - 4 } & Sig. (2-tailed) & & .000 \\
\cline { 2 - 4 } & $\mathrm{N}$ & 80 & 80 \\
\hline \multirow{3}{*}{ alienation } & Pearson Correlation & $.603^{* *}$ & 1 \\
\cline { 2 - 4 } & Sig. (2-tailed) & .000 & \\
\cline { 2 - 4 } & $\mathrm{N}$ & 80 & 80 \\
\hline
\end{tabular}

** Correlation is significant at the 0.01 level (2-tailed).

Results in Table-II indicated that stress and alienation are found to be higher among orphans as compare to normal that is, in stress, mean $=44.77$ for orphans and mean=32.57 for normal, orphans scored high on stress as compared to normal students. Same has been confirmed from their statistical value as $\mathrm{t}=3.35$ which is significant at .01 level of confidence. And in case of alienation, Mean=62.97for orphans and Mean=32.22 for normal. Orphans are found to be higher in both the conditions, as clearly shown by mean difference and confirmed by $t$-value as $t=7.40$ which is significant at .01 level. Isolating the findings, it is clearly observed that orphans are higher on alienation as compared to normal students.

Table-II Showing mean score and t-value for Stress and Alienation in both the groups i.e. Orphans \& Normal

\begin{tabular}{|c|c|c|c|c|c|c|}
\hline & Type of data & $\mathbf{N}$ & Mean & Std. Deviation & $\mathrm{t}$ & Sig. \\
\hline \multirow[t]{2}{*}{ Stress } & orphans & 40 & 44.7750 & 13.08255 & \multirow{2}{*}{3.359} & \multirow[t]{2}{*}{.001} \\
\hline & normal & 40 & 32.5750 & 18.88004 & & \\
\hline \multirow[t]{2}{*}{ Alienation } & orphans & 40 & 62.9750 & 17.57254 & \multirow{2}{*}{7.403} & \multirow[t]{2}{*}{.000} \\
\hline & normal & 40 & 32.2250 & 19.52709 & & \\
\hline
\end{tabular}

\section{DISCUSSION}

The result of the present study clearly indicated that orphans scored high on both variable i.e., stress and alienation and there are a strong relationship between stress and alienation, so all the objectives of the present research are proved. In literature a large number of studies present that supports the findings of the present study. The results from studies both made in Western countries and in African countries are much similar to each other and show that children who have been through parental lost experience more psychological difficulties than children who have not been through such a lost. The consequences in terms of difficulties are mainly seen in social withdrawal, anxiety, internalizing stress and symptoms of depression (Worden \& Silverman 1996; Thompson et al., 1998; Atwine et al., 2005; Cluver \& Gardner 2006). The same result was found by Sengendo et. al., (1997) that orphans experience more depression than nonorphans. Makame et. al. (2002) also found increased internalising problems and suicidal ideation in orphans $(n=41)$ compared with non-orphans $(n=41)$. Similarly Poulter (1996) interviewed

(C) The International Journal of Indian Psychology, ISSN 2348-5396 (e) | ISSN: 2349-3429 (p) | 169 


\section{A Comparative Study of Stress and Alienation among Orphans and Normal}

carers in 22 Zambian households with orphans, HIV+parents and controlled subjects. Carers reported orphans as more unhappy and worried than children with HIV+ parents, who were more than Makaya al., 2005) reported unhappiness, and have symptoms of running away from their new homes. (Volle et al.2002).

As for alienation is concerned, it was demonstrated in the prior studies that children who had lost their one or both parents are highly alienated as comparison to those who do not. In psychological and educational studies, for instance, adolescent alienation has been correlated with externalized behaviours such as drug use (Jessor \& Jessor, 1977), truancy, delinquency (Williamson \& Cullingford, 1998; Calabrese, 1990), and suicide (Wenz, 1979; Young, 1985). It also has been associated with internalized problems such as low self-esteem (Williamson \& Cullingford, 1998), psychological distress, and depression (Abdallah, 1997).

Many orphans are struggling with psychological problems and unmet basic needs such as food, shelter, education, and medical care. Experiences from African countries suggest that although the extended family might alleviate orphans' plight, it is unrealistic to assume that the children can escape from poverty without massive support from external sources (Bhargava \& Bigombe, 2003). Relevant government agencies should develop a realistic and sustainable approach to ensure that the children's basic needs are met. National and international agencies should be approached to raise funds for orphans' education and vocational training. More importantly, orphans are strongly stigmatized and suffer from complicated grief resolution and other psychological problems. It is, therefore, essential to provide orphans and their caregivers with mental health services, including bereavement and grief counseling, transitional services, and psychosocial support. Public health workers, school teachers, and community leaders in those areas should be trained such that they can provide basic psychosocial support and referral services to orphans in need.

\section{Acknowledgments}

The author appreciates all those who participated in the study and helped to facilitate the research process.

Conflict of Interests: The author declared no conflict of interests.

\section{REFERENCES}

Abdallah, T. (1997). Reliability and validity of Palestinian Student Alienation Scale. Adolescence, 32, 367-371

ACESS: Children speak out on poverty: Report on the ACESS Child Participation Process. Soul City, The Children's Institute, University of Cape Town; 2002. Adolescence, 35: 671-683.

Bicego G, Rutstein S, Johnson K. Dimensions of the emerging orphan crisis in sub-Saharan Africa. Soc Sci Med. 2003;56(6):1235-47. 


\section{A Comparative Study of Stress and Alienation among Orphans and Normal}

Calabrese \& Cochran (1998). Journal of Research and Clinical Studies, 4(1), 23-29.Cambridge, MA: MIT Press.

Calabrese and Adams (1999 ). Journal of Research and Clinical Studies, 4(1), 23-29. Cambridge, MA: MIT Press.

Calabrese, R. and Seldin, C. (1986). "Adolescent Alien- ation: An Analysis of the Females Response to the Secondary School Environment." The High School Journal 68, 120-125.

Calabrese, R. L., \& Adams, J. (1990). Alienation: A cause of juvenile delinquency. Adolescence, 25, 435-440.

Clearly, S. D. 2000. "Adolescent victimization and associated suicidal and violent behaviors.”

Cohen, S., Kamarck, T., \& Mermelstein, R. (1983). A global measure of perceived stress. Journal of Health and Social Behavior, 24, 385-396.

Crampin A. C., Floyd S., Glynn J. R., Madise N., Nyondo A., Khondowe M. M. (2003). The long-term impact of HIV and orphanhood on the mortality and physical well-being of children in rural Malawi. AIDS. 17(3):389-97.

Cubito, D. (1996). The psychological adjustment of a non-clinical sample of adult extra-familial adoptees. Dissertation Abstracts International: Section B: The Sciences \& Engineering, 57(2-B), 1487. (s)

Cubito, D.S., \& Brandon, K.O. (2000). Psychological adjustment in adult adoptees: Assessment of distress, depression, and anger. American Journal of Orthopsychiatry, 70(3), 408-413.

Dean, D. (1961). "Alienation: Its Meaning and Measure- ment." American Sociological Review, 26, 753-758

Fletcher, J. F. (1997). Correlates of psychosocial adjustment among adult adopted children. Dissertation Abstracts International Section A: Humanities \& Social Sciences Jul 1997, Vol 58 (1-A), p 0290.

Forehand R, Pelton J, Chance M, Armistead L, Morse E, Morse P, Stock M: Orphans of the AIDS epidemic in the United States: transition-related characteristics and psychosocial adjustment at 6 months after mother's death. AIDS Care 1999, 6:715-722.

Giese S, Meintjies H, Proudlock P: Workshop Report, National Children's Forum on HIV/AIDS (2001). The Children's Institute, University of Cape Town; 2001.

Gottfredson (1986), Alienation: A causefor juvenile delinquency. 142). Psychological Reports, 65(3), 727-73.

Hanish, L. D. and N. G. Guerra. 2000. "Predictors of peer victimization among urban youth.” Social Development, 9: 521-543.

Hans Selye, History of the Stress Concept. Ch. 2 in Leo Goldberger and Shlomo Breznitz Handbook of Stress: Theoretical and Clinical Aspects. Free Press, 1982.

Hawker, D.S.J. and M. J. Boulton. 2000. "Twenty years' research on peer victimization and psychosocial maladjustment: A meta-analytic review of crosssectional studies.” Journal of Child Psychology and Psychiatry, 41: 441-455.

Jessor, R., \& Jessor, S. L. (1977). Problem behavior and psychosocial development. New York: Academic Press.

(C) The International Journal of Indian Psychology, ISSN 2348-5396 (e) | ISSN: 2349-3429 (p) | 171 


\section{A Comparative Study of Stress and Alienation among Orphans and Normal}

Khatri, P. and J.B. Kupersmidt. 2003. “ Aggression, peer victimisation and social relationships among Indian youth.” International Journal of Behavioral Development, 27: 87-95.

Lazarus, R S, (1966). Psychological Stress and the Coping Process. New York: McGraw-Hill.

Lindblade KA, Odhiambo F, Rosen DH, DeCock KM. Health and nutritional status of orphans $<6$ years old cared for by relatives in western Kenya. Trop Med Int Health. 2003; 8(1):67-72.

M, Neckermann C, Muller O. Assessing the health status of young AIDS and other orphans in Kampala, Uganda. Trop Med Int Health. 2005;10(3):210-5.

Mackey, J., \& Ahlgren, A. (1977). Dimensions of adolescent alienation. Applied Psychological Measurement, 1, 219-232.

Makame V, Ani C, Grantham-McGregor S. Psychological well-being of orphans in Dar El Salaam, Tanzania. Acta Paediatr. 2002; 91(4):459-65.

Makaya J, Mboussou F, Bansimba T, Ndinga H, Latifou S, Ambendet, Puruehnce M: Assessment of psychological repurcussions of AIDS next to 354 AIDS orphans in Brazzaville, 2001: Barcelona. ; 2002.

Manuel P: Assessment of orphans and their caregivers' psychological well-being in a rural community in central Mozambique. London , Institute of Child Health; 2002.

Masmas TN, Jensen H, da Silva D, Hoj L, Sandstrom A, Aaby P. The social situation of motherless children in rural and urban areas of Guinea-Bissau. Soc Sci Med. 2004; 59(6):1231-9.

Mau, R. Y. (1992). The validity and devolution of a concept: Student alienation. Adolescence, 27, 731-741.

Maughan, B., Collishaw, S., \& Pickles, A., (1998). Infant adoption: Psychosocial outcomes in adulthood. Social Psychiatry \& Psychiatric Epidemiology, 33 (2), 57-65.

Minde, K. 1988. The effects of social change on the behaviour and academic performance of school age children. Unpublished paper.

Monasch R, Boerma JT. Orphanhood and childcare patterns in sub-Saharan Africa: an analysis of national surveys from 40 countries. AIDS. 2004: 18 (2):55-65.

Ntozi, J. P.M. (1997). Effect of AIDS on children: the problem of orphans in Uganda. Health Transition Review, 7, 23-40.

Nyambedha EO, Wandibba S, Aagaard-Hansen J. Changing patterns of orphan care due to the HIV epidemic in western Kenya. Soc Sci Med. 2003b; 57(2):301-11.

Nyambedha EO, Wandibba S, Aagaard-Hansen J. Retirement lost-the new role of the elderly as caretakers for orphans in Western Kenya. J Cross Cult Gerontol. 2003a;18(1):33-52.

Nyambedha, E. O., Wandibba, S., \& Aagaard-Hansen, J. (2003a). "Retirement lost” - the new role of elderly as caretakers for orphans in western Kenya. Journal of cross-cultural Gerontology, 18, 33-52.

Nyambedha, E. O., Wandibba, S., \& Aagaard-Hansen, J. (2003b). Changing patterns of orphan care due to the HIV epedemic in Western Kenya. Social science \& Medicine, 57, 301311.

(c) The International Journal of Indian Psychology, ISSN 2348-5396 (e)| ISSN: 2349-3429 (p) | 172 


\section{A Comparative Study of Stress and Alienation among Orphans and Normal}

Nyamukapa C, Gregson S. Extended families and women's roles in safeguarding orphans' education in AIDS-afflicted rural Zimbabwe. Soc Sci Med. 2005; 60(10):2155-67.

Oleke C, Blystad A, Rekdal OB. When the obvious brother is not there: political and cultural contexts of the orphan challenge in northern Uganda. Soc Sci Med. 2005; 61(12):2628-38.

Patil, R. V. Alienation Scale, Agra Psychological Research Cell, AGRA.

Pelton J, Forehand R. Orphans of the AIDS epidemic: an examination of clinical level problems of children. J Am Acad Child Adolesc Psychiatry. 2005; 44(6):585-91.

Poulter C: Vulnerable Children: a Psychological Perspective. The Nordic Africa Institute, AIDS Orphans of Africa Project; 1996.

Powell, Brasel, \& Blizzard, 1967. Iii. Eligibility For Immigration Benefits As An Orphan Adolescence, 35: 671-683.

Rafalides, M. and Hoy, W. (1971). "Student Sense of Alienation and Pupil Control Orientation of High Schools." The High School Journal 55, 101-111.

Roberts, B. R. (1987). A confirmatory factor analytic model of alienation. Social Psychology Quarterly, 50, 346-351.

Safman RM. Assessing the impact of orphanhood on Thai children affected by AIDS and their caregivers. AIDS Care. 2004; 16(1):11-9.

See, for example, this 19th century news story about The Society for the Relief of Half-Orphan and Destitute Children, or this one about the Protestant Half-Orphan Asylum.

Sengendo, J., Nambi, J. (1997). The psychological effect of orphanhood: a study of orphans I Rakai district. Health Transition Review, Supplement to Volume 7, 105-124.

Sharma, A.R., McGue, M.K., \& Benson, P.L. (1996). The emotional and behavioral adjustment of United States adopted adolescents: Part I. an overview. Children and Youth Services Review, 18, 1-2, 83-100.

Storch, E.A. and L.E. Esposito. 2003. "Peer victimization and posttraumatic stress among children.” Child Study Journal, 33: 91-99.

Storch, E.A., M.K. Nock, C. Masia-Warner and M.E. Barlas. 2003. "Peer victimization and socialpsychological adjustment in Hispanic and African- American children.” Journal of Child and Family Studies, 12: 439-452.

Swartz L: Culture and Mental Health: A Southern African View. Oxford University Press South Africa; 2002.

Thomas K, Subotsky A, Almeleh C, Stratton L: Memory Box South Africa: Manual. Cape Town, University of Cape Town; 2002.

Treating Stress And Skin Disease In Tandem by Allison Aubrey. Morning Edition, National Public Radio. 14 September 2009.

UNAIDS, UNICEF, USAID: Children on the Brink 2004: A joint report of new orphan estimates and a framework for action. UN; 2004.

UNICEF. (2003). Africa's orphaned generations. New York: UNICEF. 


\section{A Comparative Study of Stress and Alienation among Orphans and Normal}

Volle S, Tembo S, Boswell D, Bowsky S, Chiwele D, Chiwele R, Doll- Manda K, Feinberg M, Kabore I: Psychosocial baseline survey of orphans and vulnerable children in Zambia: Barcelona. ; 2002.

Wenz, F. V. (1979). Sociological correlates of alienation among adolescent suicide attempts. Adolescence, 14(53), 19-30.

Williamson, I., \& Cullingford, C. (1998). Adolescent alienation: Its correlates and consequences. Educational Studies, 24, 333--343.

Wynne, E. (1978). "Behind the Discipline Problem: Youth Suicide as a Measure of Alienation." Phi Delta Kappan, 59, 307-315.

Young (1989), Center for Social Organization of Schools Department. Johns Hopkins University, Report \#361, 72.

Young, T. J. (1985). Adolescent suicide: The clinical manifestation of alienation. High School Journal, 69, 55-59.

How to cite this article: Irshad S (2017), A Comparative Study of Stress and Alienation among Orphans and Normal, International Journal of Indian Psychology, Volume 4, Issue 2, No. 93, ISSN:2348-5396 (e), ISSN:2349-3429 (p), DIP:18.01.138/20170402, ISBN:978-1-365-78193-3 